\title{
Interactions of $\alpha$-Ketoisocaproate, Glucose and Arginine in the Secretion of Glucagon and Insulin from the Perfused Rat Pancreas
}

\author{
V. Leclercq-Meyer, J. Marchand, R. Leclercq ${ }^{1}$, and W. J. Malaisse \\ Laboratory of Experimental Medicine, Free University of Brussels, and ${ }^{1}$ Laboratory of Biological Chemistry, \\ IMC Anderlecht, Brussels, Belgium
}

\begin{abstract}
Summary. The effects of $\alpha$-ketoisocaproate (KIC, $10 \mathrm{mmol} / \mathrm{l}$ ) on glucagon and insulin release were studied in the in vitro perfused rat pancreas. The experiments were performed at low glucose concentration $(3.3 \mathrm{mmol} / \mathrm{l})$ in the absence or presence of arginine $(10 \mathrm{mmol} / \mathrm{l})$. In all the experiments $\mathrm{KIC}$ induced a marked and not rapidly reversible inhibition of glucagon release. This inhibition was more pronounced in the absence ( 76 percent) than presence of arginine (61 percent). These inhibitory patterns closely duplicated those which were seen in parallel experiments which included a rise in the concentration of glucose (from 3.3 to $11.1 \mathrm{mmol} / 1$ ). $\mathrm{KIC}$ was also a potent stimulator of insulin release. The results are compatible with the view that the intracellular metabolism of KIC and glucose plays an essential role in the regulation of glucagon release by exogenous substrates.
\end{abstract}

Key words: $\alpha$-ketoisocaproate, KIC, arginine, glucose, glucagon release, insulin release, perfusion, rat pancreas.

Glucose normally inhibits the secretion of glucagon, both in vivo and in vitro [7, 46, 47]. The intimate mechanisms by which glucose exerts its inhibitory effect are not fully elucidated but several hypotheses have been proposed. According to the glucoreceptor hypothesis, glucose interacts with specific receptors located at the $\mathbf{A}_{2}$-cell plasma membrane $[29,31,32]$. Another hypothesis postulates that the $\mathrm{A}_{2}$-cell is devoid of intrinsic glucose-sensing capacity and that the inhibitory effect of glucose is indirect and mediated by insulin [41, 47]. Finally, in the substrate-site hypothesis, it is believed that the metabolism of glucose in the $\mathrm{A}_{2}$-cell plays an essential role in the regu- lation of glucagon release. In favour of the latter concept are the observations that the $\mathrm{A}_{2}$-cells, although having a low glucose-phosphorylation capacity [18], possess a high enzymatic capacity for degradation of triose phosphates [19]. Moreover, metabolic studies conducted on $\mathrm{A}_{2}$-cell-rich islets of streptozotocintreated guinea pigs have shown that oxygen consumption, glucose oxidation, glucose utilization and ATP concentration were increased in the presence of elevated glucose levels [2, 3, 28, 38]. Other investigators, however, failed to detect major changes in metabolism, in particular in ATP concentration, in islets from rats treated with streptozotocin or alloxan $[23,24]$. These negative findings may not invalidate the metabolic hypothesis since it is well established that the sensitivity of the $A_{2}$-cell to glucose is markedly impaired in these diabetic models, as in many other forms of chronic diabetes (e. g. 6-8, 23-25, 30, 47). Besides, ATP may not be the essential messenger mediating the effect of glucose upon glucagon release.

The present work was undertaken to gain additional information on the role of intermediary metabolism in the regulation of glucagon release from the normal rat pancreas. We have compared the effects of glucose and $\alpha$-ketoisocaproate (KIC) upon glucagon release in the absence or presence of arginine. Both KIC, which is the first catabolic product of leucine, and glucose are potent insulinotropic secretagogues and are actively metabolized in rat islets $[12,13,33,34,42,43]$.

\section{Materials and Methods}

Fed female albino rats were used (mean body weight \pm SEM: 251 $\pm 6 \mathrm{~g} ; \mathrm{n}=19$ ). The perfusion technique has been described previously [15]. The animals were anaesthetized with sodium pentobarbital ( $42 \mathrm{mg} / \mathrm{kg}$ intraperitoneally) and the pancreas was isolated, 

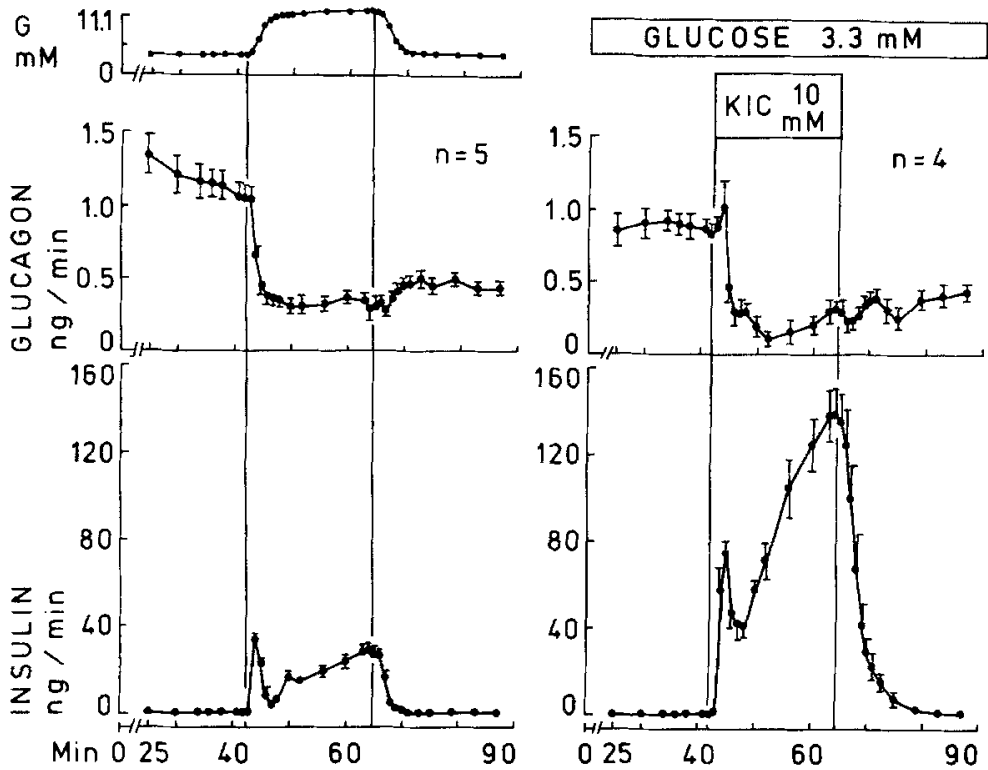

Fig. 1. The effects of $\alpha$-ketoisocaproate (KIC, $10 \mathrm{mmol} / \mathrm{l})$ upon glucagon and insulin release from the rat pancreas perfused in the presence of a low concentration of glucose ( $3.3 \mathrm{mmol} / \mathrm{l}$, panel to the right). On the panel to the left are illustrated the effects of a rise in the concentration of glucose (from 3.3 to $11.1 \mathrm{mmol} / \mathrm{l}$ )

Table 1. Glucagon secretory rates $(\mathrm{ng} / \mathrm{min})$ from the perfused rat pancreas. The results represent the mean $( \pm S E M)$ of $(\mathrm{n})$ experiments and refer to the upper panels of Fig. 1 (parts A and B) and Fig. 2 (parts C and D)

Glucagon secretory rates (ng/min)

\begin{tabular}{|c|c|c|c|c|c|c|c|}
\hline \multirow[b]{2}{*}{ Part } & \multirow[b]{2}{*}{ (n) } & & & \multirow[b]{2}{*}{$\begin{array}{l}\text { Substrates added in } \\
\text { infusion period }\end{array}$} & \\
\hline & & \multicolumn{2}{|c|}{$\begin{array}{l}\text { Substrates present in } \\
\text { basic perfusate }\end{array}$} & & $\begin{array}{l}\text { Equilibration } \\
\text { period } \\
\min 25 \text { to } 42\end{array}$ & $\begin{array}{l}\text { Infusion } \\
\text { period } \\
\text { min } 47 \text { to } 66\end{array}$ & $\begin{array}{l}\text { Post infusion } \\
\text { period } \\
\text { min } 66 \text { to } 87\end{array}$ \\
\hline A & (5) & Glucose & $3.3 \mathrm{mmol} / 1$ & $\begin{array}{r}\text { Glucose } \begin{array}{r}7.8 \mathrm{mmol} / 1 \\
(\rightarrow 11.1 \mathrm{mmol} / \mathrm{l})\end{array}\end{array}$ & $1.17 \pm 0.11$ & $0.33 \pm 0.04$ & $0.44 \pm 0.04$ \\
\hline B & (4) & Glucose & $3.3 \mathrm{mmol} / 1$ & $10.0 \mathrm{mmol} / 1$ & $0.89 \pm 0.08$ & $0.21 \pm 0.06$ & $0.34 \pm 0.04$ \\
\hline $\mathrm{C}$ & (6) & $\begin{array}{l}\text { Glucose } \\
+ \text { ARG }\end{array}$ & $\begin{array}{r}3.3 \mathrm{mmol} / 1 \\
10.0 \mathrm{mmol} / \mathrm{l}\end{array}$ & 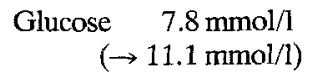 & $4.12 \pm 0.55$ & $0.86 \pm 0.11$ & $1.74 \pm 0.24$ \\
\hline $\mathrm{D}$ & (4) & $\begin{array}{l}\text { Glucose } \\
+ \text { ARG }\end{array}$ & $\begin{array}{r}3.3 \mathrm{mmol} / 1 \\
10.0 \mathrm{mmol} / \mathrm{l}\end{array}$ & $10.0 \mathrm{mmol} / 1$ & $2.83 \pm 0.56$ & $1.11 \pm 0.14$ & $1.43 \pm 0.13$ \\
\hline Non & aired & test & & $\begin{array}{l}\mathrm{B} v s \mathrm{~A} \\
\mathrm{D} v s \mathrm{C} \\
\mathrm{C} v s \mathrm{~A} \\
\mathrm{D} v s \mathrm{~B}\end{array}$ & $\begin{array}{l}\text { NS } \\
\text { NS } \\
P<0.001 \\
P<0.02\end{array}$ & $\begin{array}{l}\mathrm{NS} \\
\mathrm{NS} \\
\mathrm{P}<0.01 \\
\mathrm{P}<0.01\end{array}$ & $\begin{array}{l}\text { NS } \\
\text { NS } \\
P<0.01 \\
P<0.001\end{array}$ \\
\hline
\end{tabular}

all adjacent organs, including the duodenum, being excluded in order to avoid interference in the assay of enteric glucagon-like immunoreactivity. The rats were given intravenous heparin sodium $(125 \mathrm{U})$ at the end of the isolation procedure. The whole pancreas was perfused in situ without recycling, through the coeliac and mesenteric arteries via a camnula inserted into the aorta.

The perfusion medium comprised the following in $\mathrm{mmol} / \mathrm{l}$ : $\mathrm{NaCl}, 118.5 ; \mathrm{KCl}, 4.7 ; \mathrm{KH}_{2} \mathrm{PO}_{4}, 1.2 ; \mathrm{MgSO}_{4}, 1.2, \mathrm{NaHCO}_{3}, 25$; $\mathrm{CaCl}_{2}, 2$. It was supplemented with glucose $(3.3 \mathrm{mmol} / \mathrm{l})$, dextran $(40 \mathrm{~g} / 1, \mathrm{~T} 70$, Pharmacia, Uppsala, Sweden) and bovine albumin ( $5 \mathrm{~g} / 1$, fraction $\mathrm{V}$, Sigma, St. Louis, U. S. A.). The medium was equilibrated against a mixture of oxygen and carbon dioxide $(95: 5, \mathrm{v} / \mathrm{v})$, with a resulting $\mathrm{pH}$ of 7.4 , and entered the pancreas with a temperature of $37.5^{\circ} \mathrm{C}$. The flow rate was set around $2 \mathrm{ml} /$ min, with a resulting (mean \pm SEM) perfusion pressure of $4.47 \pm$
$0.20 \mathrm{kPa}(33.5 \pm 1.5 \mathrm{mmHg})$. When needed the substrates $\mathrm{L}(+)-$ arginine (Merck, Darmstadt, West Germany), glucose (Merck) and KIC (Sigma, St. Louis, U. S. A.) were dissolved in twice distilled water and administered through a side-arm syringe at a flow rate of $0.075 \mathrm{ml} / \mathrm{min}$ (Braun infusion pump, Melsungen, West Germany). In those experiments which were performed in the presence of arginine (final concentration in the perfusate : $10 \mathrm{mmol} / 1)$, the infusion of the amino acid was maintained throughout the perfusions. In the experiments which included an exposure to glucose (perfusate concentration : $11.1 \mathrm{mmol} / 1$ ) or the $\mathrm{Na}$ salt of $\mathrm{KIC}$ (perfusate concentration : $10 \mathrm{mmol} / \mathrm{l}$ ), the infusion of these substrates was started after a 40 min equilibration period and thereafter continued for $25 \mathrm{~min}$. In all cases the increase in osmolarity induced by the secretagogues was corrected by a $10 \mathrm{mmol} / 1$ decrease in the amount of $\mathrm{NaCl}$ in the perfusate.

Samples of the effluent were collected at $1 \mathrm{~min}$ intervals in 
Table 2. Insulin secretory rates $(\mathrm{ng} / \mathrm{min})$ from the perfused rat pancreas. The results represent the mean ( \pm SEM) of (n) experiments, and refer to the lower panels of Fig. 1 (parts A and B) and Fig. 2 (parts C and D)

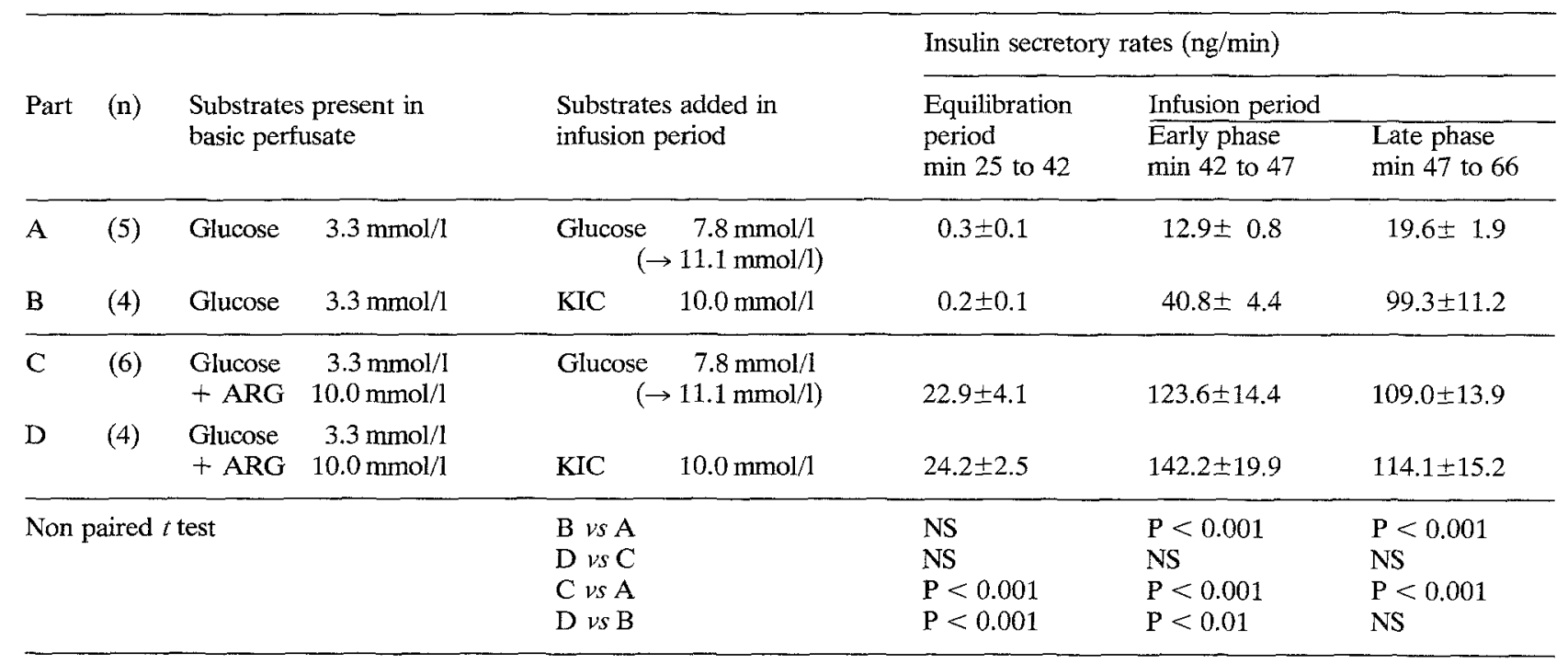

chilled tubes containing 2,000 KIU aprotinin (Trasylol; donated by Drs. G. Wald and A. Pirard, Bayer, Brussels, Belgium) and frozen at $-25^{\circ} \mathrm{C}$ until assay. At the times shown on the figures, glucagon ( $0.2 \mathrm{ml}$ aliquots) and insulin (0.01 to $0.2 \mathrm{ml}$ aliquots) were measured with individual radioimmunoassays for these hormones [17]. The tracers were ${ }^{125} \mathrm{I}$-glucagon $(480$ to $490 \mathrm{mCi} / \mathrm{mg}$, CNTS, France) and ${ }^{125} \mathrm{I}$-insulin (124 to $132 \mathrm{mCl} / \mathrm{mg}$, SORIN, Italy). The standards were beef-pork glucagon (lot 258-234-13161-1, a gift from Dr. M. A. Root, Eli Lilly and Co., Indianapolis, U.S.A.) and rat insulin (lot R 170, a gift from Dr. J. Schlichtkrull, Novo, Bagsvaerd, Denmark). Glucose was assayed in the pancreatic effluent with a glucose-oxidase method (Boehringer-Mannheim) using an AAI Technicon analyzer.

The rates of glucagon and insulin secretion were expressed as $\mathrm{ng} / \mathrm{min}$. Total glucagon or insulin release was calculated from the areas under the curves. All results in the text and the figures are given as the mean \pm SEM of $n$ experiments. Statistical analyses were conducted using two-tailed paired or non-paired $t$ tests [44]. Except if otherwise stated, results given in the text refer to the non-paired $t$ test.

\section{Results}

\section{Effects of KIC on Glucagon and Insulin Release in the Presence of $3.3 \mathrm{mmol} / \mathrm{l}$ Glucose}

The results of these experiments are shown in Figure 1 and Tables 1 and 2. The infusion of KIC first produced a slight increase in glucagon release (1.02 \pm $0.18 \mathrm{ng} / \mathrm{min}$ at $\mathrm{min} 44$ ) which, however, was not significantly different from the mean output during the equilibration period (paired $t$ test $: \mathrm{P}>0.2$ ). Thereafter, the infusion of KIC provoked a marked inhibition of glucagon release (paired $t$ test $v s$ equilibration period : $\mathrm{P}<0.001$ ). Upon the arrest of KIC infusion, the glucagon secretory rates showed some oscilla- tions but remained extensively depressed (paired $t$ test $v s$ equilibration period : $\mathrm{P}<0.001$ ). These results with KIC closely duplicated those with $11.1 \mathrm{mmol} / 1$ glucose, except that the inhibition of glucagon release occurred $1 \mathrm{~min}$ earlier in the case of glucose (Fig. 1; Table 1, part A). At no time was there any significant difference between the glucagon secretory rates recorded in the $\mathrm{KIC}$ and glucose experiments.

Concomitantly with the effects on glucagon, KIC induced a biphasic stimulation of insulin release which was much greater than that induced by glucose (Fig. 1, Table 2). Thus, in the presence of KIC the insulin secretory rate was 3 (early phase) to 5 times (late phase) as high as that seen in the presence of glucose. The stimulation of insulin release ceased abruptly upon terminating the infusion of KIC or glucose.

\section{Effects of KIC on Glucagon and Insulin Release in the Presence of $3.3 \mathrm{mmol} / \mathrm{l}$ Glucose and $10 \mathrm{mmol} / \mathrm{l}$ Arginine}

The results of the experiments performed with KIC in the presence of arginine are shown in Figure 2 and Tables 1 and 2.

In agreement with the well known inverse relationship between the effects of glucose and arginine in the alpha cell, the output of glucagon before KIC infusion was higher in the presence of arginine than in the absence of the amino acid (Table 1, equilibration period, D vs B). The infusion of KIC markedly reduced these elevated secretory rates (paired $t$ test $v s$ equilibration period : $\mathrm{P}<0.05$ ). This inhibition of 

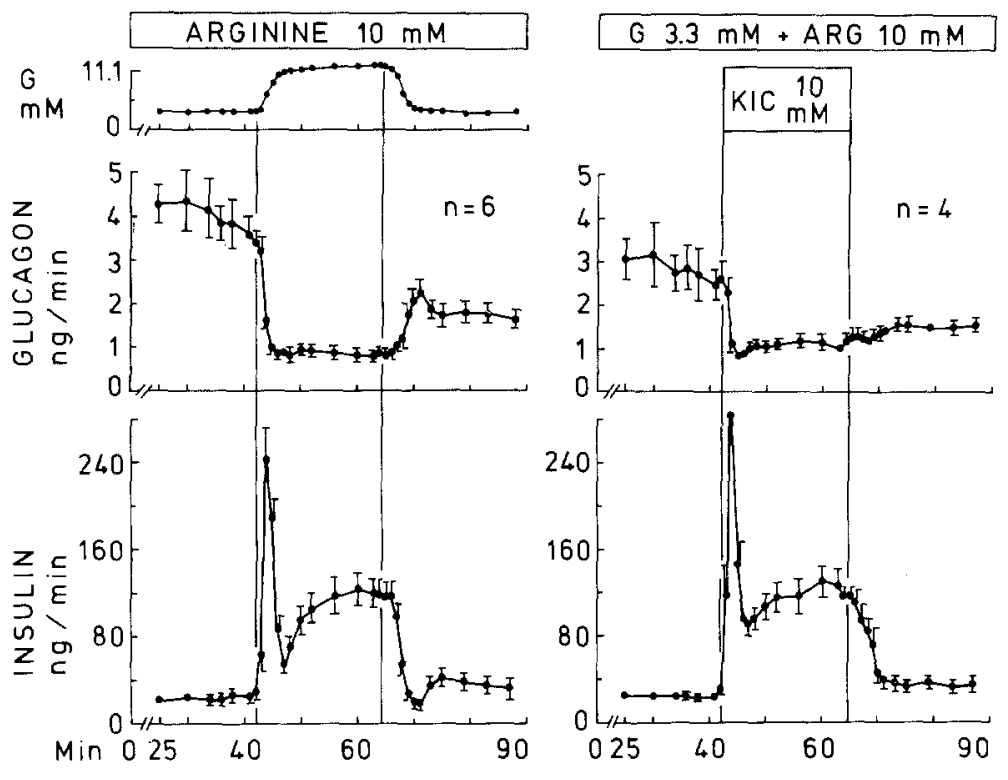

Fig. 2. The effects of $\alpha$-ketoisocaproate (KIC, $10 \mathrm{mmol} / \mathrm{l}$ ) upon glucagon and insulin from the rat pancreas perfused in the presence of a low concentration of glucose $(3.3 \mathrm{mmol} / \mathrm{l})$ and arginine $(10 \mathrm{mmol} / \mathrm{l})$ (panel to the right). On the panel to the left are illustrated the effects of a rise in the concentration of glucose (from 3.3 to $11.1 \mathrm{mmol} / 1)$ in the presence of arginine $(10 \mathrm{mmol} / \mathrm{l})$

glucagon release was only partially reversed upon the cessation of KIC infusion. Thus, despite a slight increase, the output of glucagon remained significantly lower during the postinfusion period than during the equilibration period (paired $t$ test : $\mathrm{P}<0.05$ ). This overall pattern of glucagon release mimicked the one obtained when $11.1 \mathrm{mmol} / 1$ glucose was applied to the pancreas in the presence of arginine (Fig. 2; Table 1, part C). In the glucose experiments, the glucagon secretory rate during the equilibration period was slightly higher than in the KIC experiments. The difference was not significant, however (Table 1, equilibration period, D $v s$ C). Glucose abruptly inhibited this arginine-induced glucagon release to a rate which was comparable to that seen upon the KIC infusion (Table 1, infusion period, D vs C). Following the arrest of the glucose infusion, a limited biphasic glucagon response was noticed. Despite this slight increase the late glucagon output recorded in the glucose experiments was not significantly higher than the late glucagon output in the KIC experiments (Table 1, postinfusion period, D vs C). It is of interest to note that both glucose and KIC inhibited the secretion of glucagon to a much messer extent in the presence of arginine (Table 1, infusion period, $\mathrm{C} v s \mathrm{~A}$, and $\mathrm{D} v s \mathrm{~B}$ ).

As for insulin release, in the presence of arginine KIC exerted stimulatory effects which were superimposable on those of $11.1 \mathrm{mmol} / 1$ glucose (Fig. 2). Thus, at no time throughout the perfusions was there any difference between the insulin secretory rates in the two types of experiments (Table 2, D vs C). It should be emphasised that arginine markedly augmented insulin release both at low $(3.3 \mathrm{mmol} / \mathrm{l})$ and high $(11.1 \mathrm{mmol} / \mathrm{l})$ glucose concentrations (Table 2, equilibration and infusion periods, $\mathrm{C}$ vs $\mathrm{A}$;
D vs B). Arginine also facilitated the early phase of KIC-induced insulin release (Table 2, early phase of infusion period, $\mathrm{D} v s \mathrm{~B}$ ) but did not change the late phase (Table 2, late phase of infusion period; D vs B).

\section{Discussion}

The results clearly demonstrate that in the perfused rat pancreas, in both the absence and presence of arginine, $\mathrm{KIC}(10 \mathrm{mmol} / \mathrm{l})$ induces an extensive and not rapidly reversible inhibition of glucagon release. These inhibitory effects closely resembled those seen upon the administration of an almost equimolar glucose stimulus $(11.1 \mathrm{mmol} / \mathrm{l})$. Concomitantly, KIC induced a striking stimulation of insulin release, in agreement with previous observations $[12,13,33$, $42,43]$. The fact that, at a nearly equimolar concentration and in the absence of arginine, KIC was more potent than glucose in enhancing insulin release (Fig. 1) also corroborates previous findings [12, 42].

The present data are compatible with the hypothesis that changes in intermediary metabolism of the $\mathrm{A}_{2}$-cells play a role in the regulation of glucagon release by exogenous nutrients. Proof of such an assumption awaits metabolic investigations on $\mathrm{A}_{2}$ cell-rich islets, since a dynamic study of the whole pancreas cannot bring any information as to the specific metabolic changes in the $\mathrm{A}_{2}$-cells. Nevertheless, the data available in the literature, as already stated in the introduction, suggest that there is no major difference in the metabolic handling of glucose in $\mathrm{A}_{2}$-cell-rich and whole pancreatic islets, respectively. It is conceivable that the metabolism of $\mathrm{KIC}$ is also similar in the $\mathrm{A}_{2}$-cells as in intact islets, in which 
$\mathrm{KIC}$ has been shown to increase the rates of oxygen consumption, to be converted to acetoacetate, $\mathrm{CO}_{2}$ and $\mathrm{H}_{2} \mathrm{O}$, and to increase the concentration of reduced pyridine nucleotides [12, 13]. Moreover, other findings from the literature regarding glucagon release seem to support the metabolic hypothesis. Thus, $\alpha$-D-glucose, which is preferentially metabolized in islet cells $[20,21]$, is more effective than $\beta-$ D-glucose in inhibiting glucagon release $[9,22,40]$. An inhibition of glucagon release is also observed in the presence of metabolic intermediates such as glyceraldehyde and dihydroxyacetone $[10,11,27]$. In contrast, metabolic inhibitors, such as mannoheptulose, 2-deoxyglucose, iodoacetamide, iodoacetate, 2-4-dinitrophenol and malonate, were reported to enhance glucagon secretion or to prevent glucose from suppressing amino acid induced glucagon release $[4,10,26,29,48]$.

Whether insulin participated in the KIC-induced inhibition of glucagon release cannot be decided by our experiments. Such a possibility exists, since marked elevations of insulin were observed during the KIC infusions. The least that can be said is that insulin is not the key or sole determinant of glucagon release. At the same steady-state level of insulin release $(19.6 \pm 1.9$ and $23.4 \pm 2.5 \mathrm{ng} / \mathrm{min})$, a tenfold increase in glucagon output from $0.33 \pm 0.04$ (n $=5)$ to $3.60 \pm 0.40 \mathrm{ng} / \mathrm{min}(\mathrm{n}=10)$ occurs when glucose $11.1 \mathrm{mmol} / 1$ is substituted by glucose $3.3 \mathrm{mmol} / 1$ plus arginine $10 \mathrm{mmol} / \mathrm{l}$. Conversely, glucagon release may occur at the same rate (1.04 \pm 0.08 and $1.11 \pm 0.14 \mathrm{ng} / \mathrm{min}$ ) despite a more than four-hundred-fold increase in steadystate insulin output from $0.26 \pm 0.05(\mathrm{n}=9)$ to $114.1 \pm 15.2(\mathrm{n}=$ 4) $\mathrm{ng} / \mathrm{min}$ due to the addition of $\alpha$-ketoisocaproate and arginine (both $10 \mathrm{mmol} / \mathrm{l}$ ) to a medium of low glucose concentration $(3.3 \mathrm{mmol} / \mathrm{l})$.

A last question raised by our experiments is whether the inhibitory effect of $\alpha$-ketoisocaproate upon glucagon release is relevant to the effect of leucine upon glucagon output. The effects of leucine on the secretion of glucagon have not been studied in our laboratory. The data in the literature are conflicting. Thus, the in vivo administration of L-leucine did not influence the plasma levels of glucagon $[5,35$, 39], except when infused intrapancreatically [14]. In vitro, in the sole presence of glucose, leucine has been found to enhance glucagon release $[1,36,37$, 45]. In contrast, however, some authors reported inhibition of glucagon release upon the infusion of leucine when the perfusate was supplemented with a mixture of fumarate, glutamate and pyruvate [45]. Such an inhibition is thus comparable to that obtained with KIC in the presence of arginine, for we have shown previously that arginine and a mixture of fumarate, glutamate and pyruvate exhibited equivalent glucagonotropic properties [16].
In conclusion, several questions remain to be answered in relation to the intimate mechanisms involved in the inhibitory action of KIC in the $\mathrm{A}_{2}$ cell. That the inhibitory effect of KIC parallels that of glucose, however, suggests an essential role of the intracellular metabolism of these substrates in the regulation of glucagon release.

Acknowledgements. This work was supported in part by grants 3.4527.75 and 3.4537.76 from the Belgian Foundation for Scientific Medical Research (F. R. S. M., Brussels, Belgium). We are grateful to Mrs C. Demesmaeker for secretarial help.

\section{References}

1. Assan, R., Attali, J. R., Ballerio, G., Boillot, J., Girard, J. R.: Glucagon secretion induced by natural and artificial amino acids in perfused rat pancreas. Diabetes 26, 300-307 (1977)

2. Edwards, J.C.: A-cell metabolism and glucagon secretion. Postgrad Med. J. (Suppl.) 49, 611-615 (1973)

3. Edwards, J. C., Hellerström, C., Petersson, B., Taylor, K. W.: Oxidation of glucose and fatty acids in normal and in $\mathrm{A}_{2}$-cell rich pancreatic islets isolated from guinea pigs. Diabetologia $\mathbf{8}$, 93-98 (1972)

4. Edwards, J. C., Taylor, K. W.: Fatty acids and the release of glucagon from isolated guinea-pig islets of Langerhans incubated in vitro. Biochim. Biophys. Acta 215, 310-315 (1970)

5. Fajans, S. S., Quibrera, R., Pek, S., Floyd, J. C., Christensen, H. N., Conn, J. W.: Stimulation of insulin release in the dog by a non metabolizable amino acid. Comparison with leucine and arginine. J. Clin. Endocrinol. Metab. 33, 35-41 (1971)

6. Frankel, B. J., Gerich, J. E., Hagura, R., Fanska, R. E., Gerritsen, G. G., Grodsky, G. M.: Abnormal secretion of insulin and glucagon by the in vitro perfused rat pancreas of the genetically diabetic hamster. J. Clin. Invest. 53, 1637-1646 (1974)

7. Gerich, J. C., Charles, M. A., Grodsky, G. M.: Regulation of pancreatic insulin and glucagon secretion. Annu. Rev. Physiol. 38, 353-388 (1976)

8. Gerich, J. E., Langlois, M., Noacco, C., Karam, J. H., Forsham, J. H.: Lack of glucagon response to hypoglycaemia in diabetes: evidence for an intrinsic pancreatic alpha cell defect. Science 182, 171-173 (1973)

9. Grodsky, G. M., Fanska, R., Lundquist, I.: Interrelationships between $\alpha$ and $\beta$ anomers of glucose affecting both insulin and glucagon secretion in the perfused rat pancreas. II. Endocrinology 97, 573-580 (1975)

10. Hahn, H. J., Ziegler, M.: Investigations on isolated islets of Langerhans in vitro. 16. Modification of the glucose-dependent inhibition of glucagon secretion. Biochim. Biophys. Acta 499, 362-372 (1977)

11. Hahn, H. J., Ziegler, M., Mohr, E.: Inhibition of glucagon release by glucose and glyceraldehyde on isolated islets of Wistar rats. FEBS Lett. 49, 100-102 (1974)

12. Hutton, J. C., Malaisse, W. J.: Metabolic aspects of $\alpha$ ketoisocaproate-induced insulin release in rat pancreatic islets. Diabetologia 13, 403 (1977)

13. Hutton, J. C., Sener, A., Malaisse, W. J.: The redox state of pyridine nucleotides in pancreatic islets and its relevance to 2ketoisocaproate-induced insulin release. Diabetologia 14, 241 (1978)

14. Kaneto, A., Kosaka, K.: Effects of leucine and isoleucine infused intrapancreatically on glucagon and insulin secretion. Endocrinology 91, 691-695 (1972)

15. Leclercq-Meyer, V., Marchand, J., Leclercq, R., Malaisse, W. J.: Glucagon and insulin release by the in vitro perfused rat pancreas. Influence of the colloid composition of the perfusate. Diabete Metab. 2, 57-65 (1976) 
16. Leclercq-Meyer, V., Marchand, J., Malaisse, W. J.: An arginine-like effect of the "fumarate + glutamate + pyruvate" mixture on glucagon relase. Life Sci. 20, 1193-1198 (1977)

17. Leclercq-Meyer, V., Marchand, J., Rebolledo, O., Malaisse, W. J., Leclercq, R.: A combined radioimmunoassay for glucagon and insulin. Diabetologia 11, 419-425 (1975)

18. Lundqvist, G.: Enzymatic studies of glucose phosphorylation in the glucagon producing cells of duck pancreas. Horm. Metab. Res. 4, 83-96 (1972)

19. Lundqvist, G.: Enzymatic prerequisites for ATP formation from triose phosphates in the $\mathrm{A}_{2}$ and $\mathrm{B}$ cells of the endocrine pancreas of the guinea-pig. Horm. Metab. Res. 4, 237-241 (1972)

20. Malaisse, W. J., Sener, A., Koser, M., Herchuelz, A.: Identification of the $\alpha$ stereospecific glucosensor in the pancreatic Bcell. FEBS Lett. 65, 131-134 (1976)

21. Malaisse, W. J., Sener, A., Koser, M., Herchuelz, A.: Stimulus-secretion coupling of glucose-induced insulin release. Metabolism of $\alpha$ - and $\beta$-D-glucose in isolated islets. J. Biol. Chem. 251, 5936-5943 (1976)

22. Matschinsky, F. M., Pagliara, A. S., Hover, B. A., Haymond, M. W., Stillings, G. N.: Differential effects of alpha- and beta$D$-glucose on insulin and glucagon secretion from the isolated perfused rat pancreas. Diabetes 24, 369-372 (1975)

23. Matschinsky, F. M., Pagliara, A. S., Hover, B. A., Pace, C. S., Ferendelli, J. A., Williams, A.: Hormone secretion and glucose metabolism in islets of Langerhans of the isolated perfused pancreas from normal and streptozotocin diabetic rats. J. Biol. Chem. 251, 6053-6061 (1976)

24. Matschinsky, F.M., Pagliara, A. S., Stillings, S. N., Hover, B. A.: Glucose and ATP levels in pancreatic islet tissue of normal and diabetic rats. J. Clin. Invest. 58, 1193-1200 (1976)

25. Müller, W. A., Faloona, G. R., Unger, R. H.: Abnormal alpha cell function in diabetes. Response to carbohydrate and protein ingestion. N. Engl. J. Med. 283, 109-115 (1970)

26. Müller, W.A., Faloona, G. R., Unger, R.H.: The effect of experimental insulin deficiency on glucagon secretion. J. Clin. Invest. 50, 1992-1999 (1971)

27. Norfleet, W. T., Pagliara, A.S., Haymond, W.M., Matschinsky, F. M.: Comparison of alpha- and beta-cell secretory responses in islets with collagenase and in the isolated perfused pancreas of rats. Diabetes 24, 961-970 (1975)

28. Östenson, C. G., Andersson, A., Brolin, S. E., Petersson, B., Hellerström, C.: Effects of insulin on the glucagon release, glucose utilization and ATP content of the pancreatic $\mathrm{A}_{2}$ cells of the guinea pig. In: Glucagon: its role in physiology and clinical medicine. Foa, P. P., Bajaj, J. S., Foa, N. L., (Eds.), pp. 243-254. Berlin, Heidelberg, New York: Springer 1977

29. Pagliara, A. S., Hover, B. A., Ellerman, J., Matschinsky, F. M.: Iodoacetate and iodoacetamide-induced alterations of pancreatic $\alpha$ - and $\beta$-cell responses. Endocrinology 97, 698-708 (1975)

30. Pagliara, A. S., Stillings, S. N., Haymond, M.W., Hover, B. A., Matschinsky, F. M.: Insulin and glucose as modulators of the amino acid-induced glucagon release in the isolated pancreas of alloxan and streptozotocin diabetic rats. J. Clin. Invest. 55, 244-255 (1975)

31. Pagliara, A. S., Stillings, S. N., Hover, B., Martin, D. M., Matschinsky, F. M.: Glucose modulation of amino acid-induced glucagon and insulin release in the isolated perfused rat pancreas. J. Clin. Invest. 54, 819-832 (1974)

32. Pagliara, A.S., Stillings, S. N., Zawalich, W.S., Williams, A.D., Matschinsky, F. M.: Glucose and 3-0-methylglucose protection against alloxan poisoning of pancreatic alpha and beta cells. Diabetes 26, 973-979 (1977)
33. Panten, U., Christians, J., Kriegstein, E. W., Poser, W., Hasselblatt, A.: Studies on the mechanism of D-leucine and $\alpha$ ketoisocaproic acid-induced insulin release from perifused isolated pancreatic islets. Diabetologia 10, 149-154 (1974)

34. Panten, U., Kriegstein, E. W., Poser, W., Schönborn, J., Hasselblatt, A.: Effects of l-leucine and $\alpha$-ketoisocaproate acid upon insulin secretion and metabolism of istolated pancreatic islets. FEBS Lett. 20, 225-228 (1972)

35. Pek, S., Fajans, S. S., Floyd, J.C., Jr., Knopf, R. F., Conn, J. W.: Effects upon plasma glucagon of infused and ingested amino acids and of protein meals in man. Diabetes $\mathbf{1 8}, 328$ (1969)

36. Pek, S., Santiago, J. C., Tai, T. Y.: L-leucine-induced secretion of glucagon and insulin, and the "off response" to L-leucine in vitro. I. Characterization of the dynamics of secretion. Endocrinology 103, 1208-1218 (1978)

37. Pek, S., Tai, T. Y., Crowther, R., Fajans, S. S.: Glucagon release precedes insulin release in response to common secretagogue. Diabetes $\mathbf{2 5}$, 764-770 (1976)

38. Petersson, B., Hellerström, C., Gunnarsson, R.: Structure and metabolism of the pancreatic islets in streptozotocin treated guinea pigs. Horm. Metab. Res. 2, 313-317 (1970)

39. Rocha, D. M., Faloona, G. R., Unger, R.H.: Glucagonstimulating action of 20 amino acids in dogs. J. Clin. Invest. 51, 2346-2351 (1972)

40. Rossini, A. A., Soeldner, J. S., Hiebert, J. M., Weir, G. C., Gleason, R. E.: The effect of glucose anomers upon insulin and glucagon secretion. Diabetologia 10, 795-799 (1974)

41. Samols, E., Tyler, J. M., Marks, V.: Glucagon-insulin relationships. In: Glucagon, molecular physiology, clinical and therapeutic implications. Lefebvre, P. J., Unger, R. H. (Eds.), pp. 151-173. Oxford: Pergamon Press 1972

42. Schauder, P., Schindler, B., Panten, U., Brown, J. G., Frerichs, H., Creutzfeldt, W.: Insulin release from isolated rat pancreatic islets induced by $\alpha$-ketoisocaproic acid, L-leucine, D-glucose or D-glyceraldehyde: Effect of gastric inhibitory polypeptide or glucagon. Mol. Cell. Endocrinol. 7, 115-123 (1977)

43. Schönborn, J., Westphal, P., Panten, U.: Insulin release from the isolated perfused rat pancreas induced by L-leucine, 2 aminonorbornane-2-carboxylic acid and $\alpha$-ketoisocaproic acid. Horm. Metab. Res. 7, 127-131 (1975)

44. Snedecor, G. W.: Statistical methods. Ames: Iowa State University Press 1956

45. Tai, T. Y., Pek, S., Santiago, J. C.: L-leucine-induced secretion of glucagon and insulin, and the "off response" to L-leucine in vitro. II. The role of D-glucose. Endocrinology 103, 1219-1226 (1978)

46. Unger, R. H., Lefebvre, P. J.: Glucagon physiology. In: Glucagon, molecular physiology, clinical and therapeutic implications. Lefebvre, P. J., Unger, R. H. (Eds.), pp. 213-244. Oxford: Pergamon Press 1972

47. Unger, R. H., Raskin, P., Srikant, C. B., Orci, L.: Glucagon and the A cells. Recent Prog. Horm. Res. 33, 477-517 (1977)

48. Weir, G. C., Knowlton, S. D., Martin, D. B.: Glucagon secretion from the perfused rat pancreas: studies with glucose and catecholamines. J. Clin. Invest. 54, 1403-1412 (1974)

Received: February 12, 1979, and in revised form: May 10, 1979

Dr. V. Leclercq-Meyer

Laboratory of Experimental Medicine

Free University of Brussels

Boulevard de Waterloo, 115

B-1000 Bruxelles, Belgium 